\title{
Perbandingan pengukuran luas daun kedelai dengan metode gravimetri, regresi dan scanner
}

\section{Comparations of soybean's leaf area measurement using gravimetry, regression, and scanning}

Diterima : 11 Desember 2017/Disetujui : 18 Desember 2017 / Dipublikasikan : 30 Desember 2017

CDepartment of Crop Science, Padjadjaran University

\begin{abstract}
Leaf area is one of the important parameters to determine the optimum level growth of soybean crop (Glycine max L.). Therefore, the fastest and precise technique in measurement is required. The leaf area is needed to calculate leaf area index by dividing it with wide plant canopy. Currently, measurement the leaf area using the basic method (gravimetry) is still frequently used. The other methods are by way of regression and the use of scanner tools. However, both methods have advantages and disadvantages. Therefore, in this study the comparison between two methods was designed. For the measurement of the leaf area of soybean leaf was used Anjasmoro cultivar soybean crops grown in polybags in the Hydroponic Experimental field of Faculty of Agriculture UNPAD Jatinangor from September to November 2016. The result showed that the regression and scanner method were more accurately than the gravimetric method to get leaf area soybeans. This study recommended calibrating the accuracy level for all three tested methods.
\end{abstract}

Key words : leaf area, soybean, gravimetry, regression

Sari Luas daun merupakan salah satu parameter penting yang diperlukan untuk mengetahui pertumbuhan tanaman kedelai (Glycine max L.), oleh karena itu diperlukan teknik pengukuran yang cepat dan tepat. Dengan mengetahui luas daun, maka akan diketahui indeks luas daunnya dengan cara membaginya dengan luas kanopi tanaman. Selain pengukuran luas daun menggunakan Leaf Area Meter, pengukuran dengan

\footnotetext{
Dikomunikasikan oleh Tati Nurmala

Irwan, A.W. . F. Y. Wicaksono

Prodi Agroteknologi Fakultas Pertanian UNPAD

Korespondensi : aep_wawan_irwan@yahoo.com
}

menggunakan metode dasar (gravimetri) masih sering dipergunakan. Penggunaan metode lainnya adalah dengan cara regresi dan penggunaan alat scanner, dimana metode tersebut mempunyai kelebihan dan kekurangannya masingmasing. Untuk pelaksanaan pengukuran luas daun kedelai ini digunakan tanaman kedelai kultivar Anjasmoro yang ditanam di polybag di Kebun Percobaan Hidroponik Fakultas Pertanian UNPAD Jatinangor dari bulan September sampai dengan bulan November 2016. Setelah dilakukan perhitungan, dapat disimpulkan bahwa metode regresi dan metode scanner mendapatkan hasil pengukuran luas daun kedelai yang lebih teliti dibandingkan dengan metode gravimetri. Perlu disarankan peng-gunaan leaf area meter untuk kalibrasi terhadap tingkat ketelitian dari ketiga metode yang diuji.

Kata kunci : luas daun, kedelai, gravimetri, regresi

\section{Pendahuluan}

Daun merupakan salah satu organ tanaman yang penting, karena pada daun terdapat bagian/komponen dan sekaligus tempat berlangsungnya proses fotosintesis dan transpirasi yang menentukan pertumbuhan tanaman. Oleh karena itu luasdaun merupakan salah satu parameter penting dalam analisis pertumbuhan tanaman. Setelah diketahui luas daun, maka akan didapat Indeks Luas Daun (ILD) dengan cara membagi luas daun dengan luas kanopi.

Dalam analisis pertumbuhan tanaman, perkembangan daun menjadi perhatian utama. Berbagai ukuran dapat digunakan, seperti pengukuran indeks luas daun (ILD), nisbah luas daun (NLD) dan nisbah berat daun (NBD) pada waktu tertentu. Perubahan-perubahan selama 
pertumbuhan mencerminkan perubahan bagian yang aktif berfotosintesis (Gardner, et al, 2007)

Untuk pengukuranluas daun tentunya kecepatan dan ketepatan pengukuran sangat diperlukan agar didapat dapta yang akurat, namun demikian ketepatan dan kecepatan pengukuran sangat tergantung pada alat dan cara atau teknik pengukuran. Pengukuran luas daun dapat dilakukan dengan memetik daun (sampel dektruksi) maupun tanpa memetikdaun.

Bilamana pengukuran harus dilakukan dengan cara memetik daun tersebut, maka harus disediakan tanaman sampel destruksi.

Pengukuran daun dengan tidak memetik daun (non destruksi) dapat dilakukan dengan menggunakan persamaan atau rumus.

Pengukuran luas daun dengan tidak harus memetik daun merupakan teknik pengukuran yang lebih baik karena tanaman tidak rusak dan pengukuran cepat serta tidak mensyaratkan peralatan yang mungkin sulit tersedianya.

Pada karet digunakan persamaan regresi terhadap ukuran panjang dan lebar daun (Suhendry dan Alwi, 1987; Lim dan Narayanan, 1972).

Pada beberapa tanaman pangan seperti jagung dan kedelai digunakanfaktor koreksi terhadap luas daun yang diperoleh dari pengukuran panjang dan lebar daun (Pearce et.al., 1988) demikian pula pada daun nangka (Goonasekera, 1978). Sehubungan dengan pentingnya teknik pengukuran luas daun, baik dengan cara destruksi maupun non-destruksi, perlu dikaji beberapa metode pengukurannya. Pada artikel ini, kami membahasnya dengan metode gravimetri, regresi dan penggunaan scanner sekaligus untuk mengetahui tingkat ketelitiannya dengan cara membandingkan hasil pengukurannya diantara ketiga metode tersebut sehingga dapat diketahui metode mana yang dapat digunakan dengan ketelitian yang memadai.

\section{Bahan dan Metode}

Untuk pelaksanaan pengukuran luas daun kedelai ini digunakan tanaman kedelai kultivar Anjasmoro yang ditanam di polybag di Kebun Percobaan Hidroponik Fakultas Pertanian Unpad Jatinangor dari bulan September sampai dengan bulan November 2016.

Daun-daun yang diukur secara acak sejumlah 30 lembar, yaitu 10 lembar dari bagian atas tanaman kedelai, 10 lembar dari bagian tengah tanaman dan 10 lembar dari bagian bawah tanaman agar didapat sampel daun yang representatif. Untuk pengolahan data, dari 30 daun, hasil pengukuran yang diperoleh sejumlah 15 data, diulang 2 kali sehingga berjumlah 30 daun.

Daun-daun kedelai sampel tersebut diukur luas daunnya dengan menggunakan 3 metode pengukuran yaitu dengan metode gravimetri, rumus regresi dan penggunaan scanner dibantu dengan software IrfanViev yang bersifat Free, dapat didownload pada http://irfanview.com. Sanner yang dipergunakan dengan resolusi 300 dpi.

\section{Metode Gravimetri}

Untuk pelaksanaan metode gravimetri, sebagai berikut :

1. Digunakan pola-pola daun (replika daun) yang digambar pada suatu kertas polos.

2. Replika daun tersebut ditimbang dengan menggunakan timbangan analitik

3. Membuat potongan kertas $10 \mathrm{~cm} \times 10 \mathrm{~cm}$, lalu ditimbang

4. Menghitung luas daun dengan menggunakan rumus :

Luas daun $=\frac{\text { bobot replika daun }}{\text { bobot kertas } 10 \mathrm{~cm} \times 10 \mathrm{~cm}} \times 100 \mathrm{~cm} 2$

\section{Metode Regresi}

Untuk pelaksanaan metode regresi, sebagai berikut :

1. Panjang dan lebar daun diukur pada masing-masing sampel daun kedelai

2. Digunakan data dari metode gravimetri

3. Membuat persamaan model regresi linear $Y=a+b X$ dengan $a$ dan $b$ diperoleh dari rumus regresi sebagai berikut :

$$
\begin{gathered}
\mathrm{b}=\frac{n \cdot \sum X Y-\sum X \cdot \Sigma Y}{n \cdot \sum X^{2}-\left(\sum X\right)^{2}} \\
\mathrm{a}=\frac{\sum Y-b \cdot \sum X}{n}
\end{gathered}
$$

4. Menghitung luas daun dengan persamaan regresi linear yang telah diperoleh.

\section{Metode Scanner dengan Software IrfanView :}

Untuk pelaksanaan metode scanner, sebagai berikut :

1. Scan sampel daun kedelai dengan scanner dengan resolusi 300 dpi.

2. Jalankan software IrvanView-nya

3. Klik Image lalu decrease color depth, dipilih 2 colors. 
4. Klik Increase color depht, dipilih 16 color

5. Pilih menu histrogram, pilih luminosity (gray) dan geser kursor ke sebelah paling kiri dari Image Histrogram, didapat jumlah pixel dari daun kedelai yang discan.

6. Pixel yang didapat, dimasukkan ke rumus perhitungan luas daun:

$$
\text { Luas daun }=\frac{\text { pixel } \times 2.54^{2}}{D P I^{2}} \mathrm{~cm}^{2}
$$

\section{Hasil dan Pembahasan}

Data hasil pengukuran tersaji pada Tabel 1 sampai dengan Tabel 4.

Tabel 1. Hasil Pengukuran Sampel Daun untuk Metode Gravimetri.

\begin{tabular}{clccc}
\hline $\begin{array}{c}\text { Tanaman kedelai } \\
\text { Sampel }\end{array}$ & $\begin{array}{c}\text { Panjang } \\
(\mathrm{cm})\end{array}$ & $\begin{array}{c}\text { Lebar } \\
(\mathrm{cm})\end{array}$ & $\begin{array}{c}\text { Bobot } \\
\text { replika } \\
\text { Daun }(\mathrm{g})\end{array}$ \\
\hline \multirow{2}{*}{1} & Atas & 4.6 & 3.4 & 0.11 \\
& Tengah & 11.6 & 8.6 & 0.71 \\
& Bawah & 5.9 & 4.3 & 0.11 \\
\hline \multirow{2}{*}{2} & Atas & 6.3 & 3.3 & 0.12 \\
& Tengah & 11.9 & 7.4 & 0.70 \\
& Bawah & 9.1 & 6.1 & 0.32 \\
\hline \multirow{2}{*}{3} & Atas & 7.9 & 4.8 & 0.25 \\
& Tengah & 11.3 & 8.1 & 0.59 \\
& Bawah & 8.3 & 5.3 & 0.22 \\
\hline \multirow{2}{*}{4} & Atas & 8.1 & 4.9 & 0.23 \\
& Tengah & 11.1 & 8.1 & 0.59 \\
& Bawah & 5.3 & 3.7 & 0.12 \\
\hline \multirow{2}{*}{5} & Atas & 8.7 & 5.7 & 0.27 \\
& Tengah & 11.8 & 8.9 & 0.73 \\
& Bawah & 8.6 & 6.4 & 0.24 \\
\hline
\end{tabular}

Tabel 2. Hasil Pengukuran Sampel Daun untuk Metode Regresi.

\begin{tabular}{|c|c|c|c|c|c|c|}
\hline \multicolumn{2}{|c|}{ Tan. kedelai } & \multirow{2}{*}{$\begin{array}{c}X \\
(p \times l)\end{array}$} & \multirow{2}{*}{$\begin{array}{c}\mathrm{Y} \\
\text { (Gravi- } \\
\text { metri) }\end{array}$} & \multirow[t]{2}{*}{$\mathrm{X}^{2}$} & \multirow[t]{2}{*}{$\mathrm{Y}^{2}$} & \multirow[t]{2}{*}{$X Y$} \\
\hline $\begin{array}{l}\text { Sam- } \\
\text { pel }\end{array}$ & Daun & & & & & \\
\hline \multirow{3}{*}{1} & Atas & 15.64 & 22,0 & 244.61 & 484.00 & 344.08 \\
\hline & Tengah & 99.76 & 142,0 & 9952.06 & 20164.00 & 14165.92 \\
\hline & Bawah & 25.37 & 22,0 & 643.64 & 484.00 & 558.14 \\
\hline \multirow{3}{*}{2} & Atas & 20.79 & 24,0 & 432.22 & 576.00 & 498.96 \\
\hline & Tengah & 88.06 & 140,0 & 7754.56 & 19600.00 & 12328.40 \\
\hline & Bawah & 55.51 & 64,0 & 3081.36 & 4096.00 & 3552.64 \\
\hline \multirow{3}{*}{3} & Atas & 37.92 & 50,0 & 1437.93 & 2500.00 & 1896.00 \\
\hline & Tengah & 91.53 & 118,0 & 8377.74 & 13924.00 & 10800.54 \\
\hline & Bawah & 43.99 & 44,0 & 1935.12 & 1936.00 & 1935.56 \\
\hline \multirow{3}{*}{4} & Atas & 39.69 & 46,0 & 1575.30 & 2116.00 & 1825.74 \\
\hline & Tengah & 89.91 & 118,0 & 8083.81 & 13924.00 & 10609.38 \\
\hline & Bawah & 19.61 & 24,0 & 384.55 & 576.00 & 470.64 \\
\hline \multirow{3}{*}{5} & Atas & 49.59 & 54,0 & 2459.17 & 2916.00 & 2677.86 \\
\hline & Tengah & 105.02 & 146,0 & 11029.20 & 21316.00 & 15332.92 \\
\hline & Bawah & 55.04 & 480 & 3029.40 & 2304.00 & 2641.92 \\
\hline \multicolumn{2}{|c|}{ TOTAL $\left(\sum\right)$} & 837.43 & 1062,00 & 60420.67 & 106916.00 & 79638.70 \\
\hline
\end{tabular}

Persamaan model regresi linear $Y=a+b X$ dengan a dan $b$ diperoleh dari rumus:

$$
\begin{aligned}
\mathrm{b} & =\frac{n \cdot \sum X Y-\sum X \cdot \sum Y}{n \cdot \sum X^{2}-\left(\sum X\right)^{2}} \\
& =\frac{(15)(79638.70)-(837.43)(1062.0)}{15 X(60420.67)^{2}-(837.43)^{2}} \\
& =1.49
\end{aligned}
$$

sedangkan :

$$
\begin{aligned}
\mathrm{a} & =\frac{\sum Y-b \cdot \sum X}{n} \\
& =\frac{1062.0-(1.49)(837.43)}{15} \\
& =-12.32
\end{aligned}
$$

Jadi, persamaan regresi liniernya adalah $\mathbf{Y}=$ (-

\begin{tabular}{|c|c|c|c|}
\hline \multicolumn{2}{|c|}{ Tanaman kedelai } & \multirow{2}{*}{$\begin{array}{c}X \\
(p \times 1)\end{array}$} & \multirow{2}{*}{$\begin{array}{c}Y \\
Y=(-12.32)+1.49 X\end{array}$} \\
\hline Sampel & Daun & & \\
\hline \multirow{3}{*}{1} & Atas & 15.64 & 10.97 \\
\hline & Tengah & 99.76 & 136.20 \\
\hline & Bawah & 25.37 & 25.45 \\
\hline \multirow{3}{*}{2} & Atas & 20.79 & 18.64 \\
\hline & Tengah & 88.06 & 118.79 \\
\hline & Bawah & 55.51 & 70.33 \\
\hline \multirow{3}{*}{3} & Atas & 37.92 & 44.14 \\
\hline & Tengah & 91.53 & 123.95 \\
\hline & Bawah & 43.99 & 53.17 \\
\hline \multirow{3}{*}{4} & Atas & 39.69 & 46.77 \\
\hline & Tengah & 89.91 & 121.54 \\
\hline & Bawah & 19.61 & 16.88 \\
\hline \multirow{3}{*}{5} & Atas & 49.59 & 61.51 \\
\hline & Tengah & 105.02 & 144.03 \\
\hline & Bawah & 55.04 & 69.63 \\
\hline
\end{tabular}
12.32) + 1,49X

Dengan menggunakan rumus persamaan $\mathrm{Y}=(-$ 12.32) + 1,49X maka didapatkan luas daun sebagai berikut :

Tabel 3. Hasil Perhitungan Persamaan Regresi Linier untuk nilai $X$ dan $Y$

3. Hasil pengukuran sampel daun untuk metode scanner dengan software IrfanView

Daun kedelai discan dengan resolusi 300 dpi disajikan pada Tabel 4.

Faktor yang penting untuk diperhatikan dalam mengukur luas daun adalah ketepatan hasil pengukuran dan kecepatan pengukuran. Masing-masing faktor tersebut memiliki kepentingan sendiri dalam penggunaannya, seperti pada pengukuran laju fotosintesis dan proses metabolisme lain tentunya ketepatan pengukuran yang diperlukan. Untuk pengukuran indek 
luas dauntentunya kecepatan pengukuran, namun demikian ketepatan dan kecepatan pengukuran sangat tergantung pada alat dan cara atau teknik pengukuran.

Tabel 4. Hasil Scan Daun Kedelai dengan Resolusi 300 dpi.

\begin{tabular}{|c|c|c|c|}
\hline \multicolumn{2}{|c|}{ Tanaman kedelai } & \multirow{2}{*}{$\begin{array}{l}\text { X (DPI) } \\
\text { pixel }\end{array}$} & \multirow{2}{*}{$\begin{array}{c}\text { Y (luas } \\
\text { daun), }\left(\mathrm{cm}^{2}\right)\end{array}$} \\
\hline Sampel & Daun & & \\
\hline \multirow{3}{*}{1} & Atas & 153430 & 11.00 \\
\hline & Tengah & 1900346 & 136.23 \\
\hline & Bawah & 355283 & 25.47 \\
\hline \multirow{3}{*}{2} & Atas & 259763 & 18.62 \\
\hline & Tengah & 1657256 & 118.80 \\
\hline & Bawah & 981543 & 70.36 \\
\hline \multirow{3}{*}{3} & Atas & 615527 & 44.12 \\
\hline & Tengah & 1729622 & 123.99 \\
\hline & Bawah & 741291 & 53.14 \\
\hline \multirow{3}{*}{4} & Atas & 652687 & 46.79 \\
\hline & Tengah & 1695777 & 121.56 \\
\hline & Bawah & 235656 & 16.89 \\
\hline \multirow{3}{*}{5} & Atas & 858494 & 61.54 \\
\hline & Tengah & 2009588 & 144.06 \\
\hline & Bawah & 971582 & 69.65 \\
\hline
\end{tabular}

Untuk menghitung luas daunnya :

$$
\text { Luas daun }=\frac{\text { pixel } X 2.54^{2}}{D P I^{2}} \mathrm{~cm}^{2}
$$

Pengukuran luas daun dapat dilakukan dengan memetik daun maupun tanpa memetik daun. Bilamana pengukuran harus dilakukan dengan cara memetik daun bersangkutan, maka tanaman mengalami kerusakan daun. Sebaliknya pengukuran dengan tanpa memetik daun, maka tanaman akan tetap tumbuh baik karena daun-daun tidak berkurang.

Pengukuran daun dengan tidak memetik daun dapat dilakukan dengan menggunakan persamaan atau rumus. Pengukuran luas daun dengan tidak harus memetik daun merupakan teknik pengukuran yang lebih baik karena tanaman tidak rusak dan pengukuran cepat serta tidak mensyaratkan peralatan yang mungkin sulit tersedianya.

Pada beberapa tanaman pangan seperti jagung dan kedelai digunakan faktor koreksi terhadap luas daun yang diperoleh dari pengukuran panjang dan lebar daun (Pearce et al., 1988). Selain itu, dapat menggunakan metode gravimetri.

Pada prinsipnya luas daun ditaksir melalui perbandingan bobot (gravimetri) dilakukan dengan menggambar daun yang akan ditaksir luasnya pada sehelai kertas, yang menghasilkan replika (tiruan) daun. Replika daun kemudian digunting dari kertas yang berat dan luasnya sudah diketahui. Luas daun kemudian ditaksir berdasarkan perbandingan berat replika daun dengan berat total kertas dikalikan dengan luas kertas konversi (Jumin, 2005).

Pada tanaman kedelai terlihat perkembangan indeks Luas Daun setelah awal pertumbuhan, terjadi peningkatan yang cepat yang mendekati linier sampai fase pembungaan, saat dicapai ILD 5 - 8. Setelah mencapai maksimum kemudian menurun dengan cepat karena daundaun bawah luruh. Selama fase pengisian biji sampai fase masak fisiologis, nilai ILD berkisar antara 4 - 6 (Shibbles, et al, 1975).

Blad dan Baker mengemukakan hubungan ILD selama pertumbuhan tanaman kedelai berdasarkan hasil penelitian pada varietas Chippena 64 dan Hank, diperoleh bahwa setelah awal pertumbuhan tanaman kedelai, terlihat peningkatan sesuai bertambahnya umur tanaman, kemudian turun dan ILD maksimum dicapai pada saat jumlah daun dan ukuran daun maksimum.

Variasi Ukuran Helaian Daun. Ukuran daun pada saat fase bibit relatif lebih kecil dibandingkan dengan daun pada saattanaman dewasa. Ukuran helaian daun saat fase bibit lebih seragam dibandingkan ukuran helaian daundari tanaman dewasa. Pada tanaman dewasa ukuran helaian daun bervariasi dari yangberukuran kecil, berukuran sedang hingga berukuran besar. Ukuran daun yang lebih kecilbiasanya diperoleh pada percabangan yang terletak di bawah. Daun-daun yang berada di tengah biasanya lebih besar, dan kemudian berukuran kecil lagi pada bagian ujung percabangan. Perbedaan ukuran helaian daun pada tanaman yang sama disebabkan perbedaan tingkat perkembangan tanaman, sedangkan perbedaan ukuran helaian daun antar tanamantentunya disebabkan oleh perbedaan tingkat pertumbuhan dan perkembangan dan perbedaan lingkungan tumbuh (Finkedey, 2005).

Pengukuran Luas Daun. Untuk pengukuran luas daun dengan metode gravimetri dilakukan dengan cara membandingkan bobot replika/pola daun yang digunakan pada kertas polos dengan bobot kertas konversi dengan ukuran $10 \times 10 \mathrm{~cm}^{2}$ dikalikan luas kertas konversi itu sendiri. Selanjutnya pengukuran luas daun dilakukan dengan metode persamaan regresi. Dengan metode ini pengukuran luas daun dengan tidak harus memetik daun merupakan teknik pengukuran yang lebih baik 
karena tanaman tidak rusak dan pengukuran cepat serta tidak mensyaratkan peralatan yang mungkin sulit tersedianya. Metode ini menggunakan faktor koreksi terhadap luas daun yang diperoleh dari pengukuran panjang dan lebar daun serta hasil dari metode gravimetri.

Hasil pengukuran luas daun menunjukkan bahwa luas helai daun tanaman kedelai bervariasi tergantung metode pengukuran yang digunakan, walaupun sampel daun kedelainya sama.Ukuran daun yang lebih kecil biasanya diperoleh pada percabangan yang terletak di bawah. Daun-daun yang berada ditengah biasanya lebih besar, dan kemudian berukuran kecil lagi pada bagian ujung percabangan (Finkedey, 2005).

Dengan menggunakan berbagai metode, hasil yang didapatkan berbeda pula, namun hal sama yang dapat diperoleh adalah daun tengah memiliki luas daun yang paling besar, ini disebabkan oleh perbedaan tingkat perkembangan dan pertumbuhan tanaman itu sendiri. Setiap tanaman memiliki pola dan kecepata pertumbuhan tertentu tergantung kepada usia tanaman dan fase tanaman (Weier, dkk., 1974). Menurut Kramer dan Kozlowski (1960) setiap tanaman memiliki karakteristik tertentu dalam pembentukan organ tanaman, termasuk perkembangan daun, dimana di dalamnya terdapat klorofil yang dapat mempengaruhi tingkat fotosintesis.

Atas dasar tersebut, untuk mendapatkan data yang lebih akurat sebagai tanaman sampel, maka pada pengukuran dengan ketiga metode ini, dipilih dari ketiga bagian tanaman kedelai tersebut.

Dari ketiga metode yang digunakan untuk menghitung luas daun dapat diketahui bahwa metode rumus regresi dan penggunaan scanner merupakan metode yang mempunyai akurasi yang lebih baik dibandingkan dengan metode gravimetri, terbukti dari hasil pengukuran luas daunnya, metode regresi dan scanner adalah hampir sama, namun metode gravimetri, perbedaannya cukup besar dibandingkan dengan kedua metode tersebut. Persamaan rumus regresi yang didapatkan berdasarkan perhitungan yaitu $Y=(-12.32)+1,49 \mathrm{X}$.

\section{Kesimpulan dan Saran}

Berdasarkan hasil percobaan dapat disimpulkan sebagai berikut:
1. Metode regresi dan scanner lebih baik tingkat ketelitiannya dibandingkan dengan metode gravimetri untuk mengukur luas daun kedelai.

2. Persamaan rumus regresi yang didapatkan berdasarkan perhitungan yaitu $\mathrm{Y}=(-12.32)+$ 1,49X.

3. Pengukuran luas daun dengan berbagai metode mendapatkan hasil yang berbeda.

\section{Saran:}

Untuk mengetahui tingkat akurasi metode mana yang lebih teliti, sebaiknya digunakan leaf area meter yang sudah dikalibrasi sebagai pembandingnya.

\section{Daftar Pustaka}

Kramer, P.J. dan Kozlowski, T.T. 1960. Physiology of Trees. McGraw Hill Book Company. London. pp 400;418-421.

Finkeldey, R. 2005. An Introduction to Tropical Forest Genetics. Diterjemahkan Djamhuri, E. et.al. Pengantar Genetika Hutan Tropis. ASEAN-EU University Network Programme (AUNP). Bogor.

Gardner, F. P; R. B. Pearce dan R. L. Mitchell. 2007. Fisiologi Tanaman. PT Gramedia. Jakarta.

Goonasekera, G.A.J.P.R. 1978. A General Regression Equation for The Estimation of LeafArea. J. Rub. Res. Inst. Srilanka 55:29-33.

Jumin, H. B. 2005. Dasar-Dasar Agronomi. Edisi Revisi. P. T. Raja Grafindo Persada. Jakarta.

Lim, T.M. and K. Narayanan. 1972. Estimation of The Area of Rubber Leaves (Hevea brasiliensis Muell. Arg). Using Two Leaf-let Parameter. Expt. Agric. 8(4):311-314.

Pearce, SC., G.M. Clark, G.V. Dyke, R.E. Kempson. 1988. A Mannual of Crop Experimentation. London, Charles Griffin \& Co.

Shibbles, Anderson and Gibson. 1975. Physiological Processes Limiting Plant Productivity. London, Boston, Sydney, Wellington, Durban, Toronto.

Suhendry, I. dan N. Alwi. 1987. Beberapa Metode Pengukuran Luas Daun Klon Karet. Bulletin Perkaretan. 5 (3):67-71.

Weier, T.E., C.R. Stocking, and M.G. Barbour. 1974. Botany. An Introduction to Plant Biology. Fifth Edition. Wiley International Edition. New York. 